\title{
CHANGES OF LETTUCE ZINC CONTENT IN HYDROCULTURAL CULTIVATION
}

\author{
Zsuzsanna Tóthné Taskovics ${ }^{1 *}$, András Kovács ${ }^{1}$, Attila Hüvely ${ }^{2}$ and Judit Petö ${ }^{2}$ \\ 1Department of Horticulture, Faculty of Horticulture and Rural Development, John von Neumann University, \\ Hungary \\ ${ }^{2}$ Department of Agricultural Science, Faculty of Horticulture and Rural Development, John von Neumann \\ University, Hungary \\ https://doi.org/10.47833/2020.2.AGR.037
}

Keywords:
vegetable
minerals
health
lettuce
zinc
Article history:
Received 10 May 2020
Revised 20 May 2020
Accepted 25 May 2020

\section{Introduction}

Nowadays people are increasingly exposed to pollutants that deteriorate health and weaken the immune system. One of the best ways to reduce the negative effect is a healthy diet. Scientific research in this subject has shown that plant-based foods contain a number of ingredients that strengthen certain functions, making the immune system more effective. This is where the concept of functional food comes from. "Food can be considered functional if it has a detectable positive effect on one or more target functions in the body that help achieve better health or a reduction in the risk of disease" $[1,4]$.

Among nutrients, zinc is an important mineral for maintaining health. It plays a role in the formation of new tissues, the production of energy in the body, the support of the immune system, digestive processes, the regulation of blood sugar levels, and the solution of skin problems. We need it on a daily basis, but only in small quantities (8-12 mg / day). The body is not able to produce on its own, therefore it comes from external sources - we get it from the food. In addition, adequate intake should be provided [3,5].

Many of our foods are found in foods: red meats, crabs, mussels, wheat germ, nuts and nuts. Among the vegetables, asparagus, chard, spinach, shiitake mushrooms and lettuce have higher zinc content [2].

Lettuce as a vegetable is very popular among consumers. Due to the development of cultivation technology and its short growing time, it can be consumed fresh at any time of the year. Due to its good nutrient storage capacity, the amount of absorbed nutrients can be easily detected in it [6]. In hydroponic cultivation, the addition of nutrients can be well controlled in terms of application period and the amount applied [7].

\footnotetext{
* Corresponding author. Tel.: +36 76517631

E-mail address: tothne.zsuzsanna@kvk.uni-neumann.hu
} 
Our goal was to produce a functional food based on the above, in which we can increase the zinc content by applying nutrient. Due to its favourable properties, we chose lettuce and examined whether increasing the zinc content of the nutrient solution increases the zinc content of the lettuce head and whether it has any effect on the development of the head weight.

\section{Method}

The experiment was set up in the greenhouse of the Faculty of Horticulture and Rural Development of the John von Neumann University in hydroponic cultivation. Seedlings were placed in stone wool cubes in plant support channels in which nutrient solution was flowed under the plant rows. Thanks to the small-channel solution, different zinc-containing nutrient solutions could be applied to the plants in isolation according to the treatments and replicates.

Planting took place in the autumn growing season, on 05.09.2019. Ice lettuce and coloured lettuce varieties were chosen as experimental plants. Three treatments and three replicates per treatment were set. Three plants were planted from iceberg lettuce and 5 plants from colour lettuce per replicate. The planning of the treatments was based on the nutrient solution recommendation of the hydroculture lettuce, where $0.25 \mathrm{mg}$ of zinc is recommended in 1 litre of standard nutrient solution. Thus, the following treatments were applied:

Treatment 1: $0.5 \mathrm{mg} / \mathrm{I} \mathrm{Zn}$

Treatment 2: $0.75 \mathrm{mg} / \mathrm{I} \mathrm{Zn}$

Treatment 3: $1 \mathrm{mg} / \mathrm{I} \mathrm{Zn}$

Zinc was added from October the 4th. The medium was changed every two weeks and the appropriate amount of zinc was added to the appropriate medium.

The experiment was terminated on the $15^{\text {th }}$ of November , 2019. At this time, plant samples were taken according to the treatments and replicates, which were sent to the Soil and Plant Examination Laboratory of the Faculty of Horticulture. At the same time the lettuce heads were weighed.

\section{Results}

In evaluating the laboratory test results, we worked with the average of the obtained results per replicate. We first examined the change in the weight of lettuce heads under the effect of different amounts of zinc applied (Figure 1.).

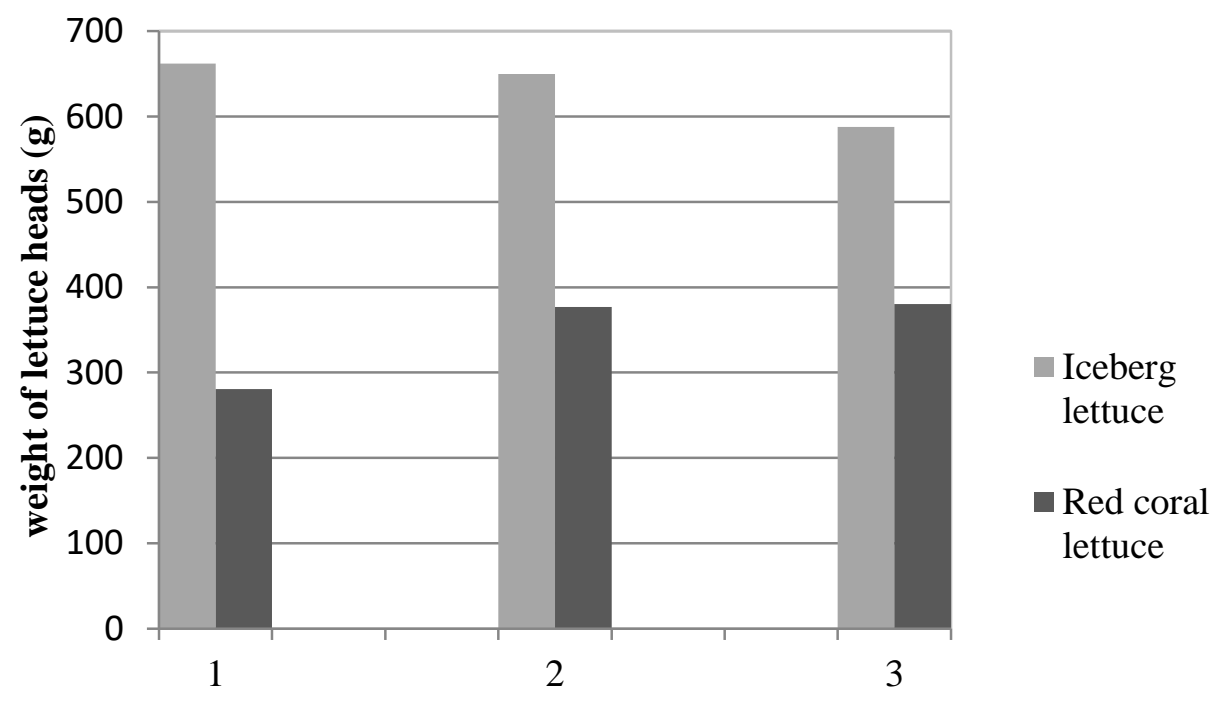

Figure 1. Changes in lettuce head weight as a result of treatments 
In the case of iceberg lettuce, the two lower doses resulted similar weight in the formation of heads, while at the highest dose we measured lower head weight compared to the previous two. However, the difference between the values was not significant. In the case of the coloured lettuce, we cannot actually talk about a specific lettuce head, as in the case of the iceberg lettuce. Here we were able to measure the leaf mass consisting of separate leaves. In this case, the leaf weight (head weight) increased with increasing zinc content, in contrast to what was observed with iceberg lettuce. The weight of lettuce heads measured in treatment 1 differed more from the other two treatments. The difference between the head weights of treatments 2 and 3 was negligible.

The values shown in Figure 2 were obtained by examining the zinc content of the leaves.

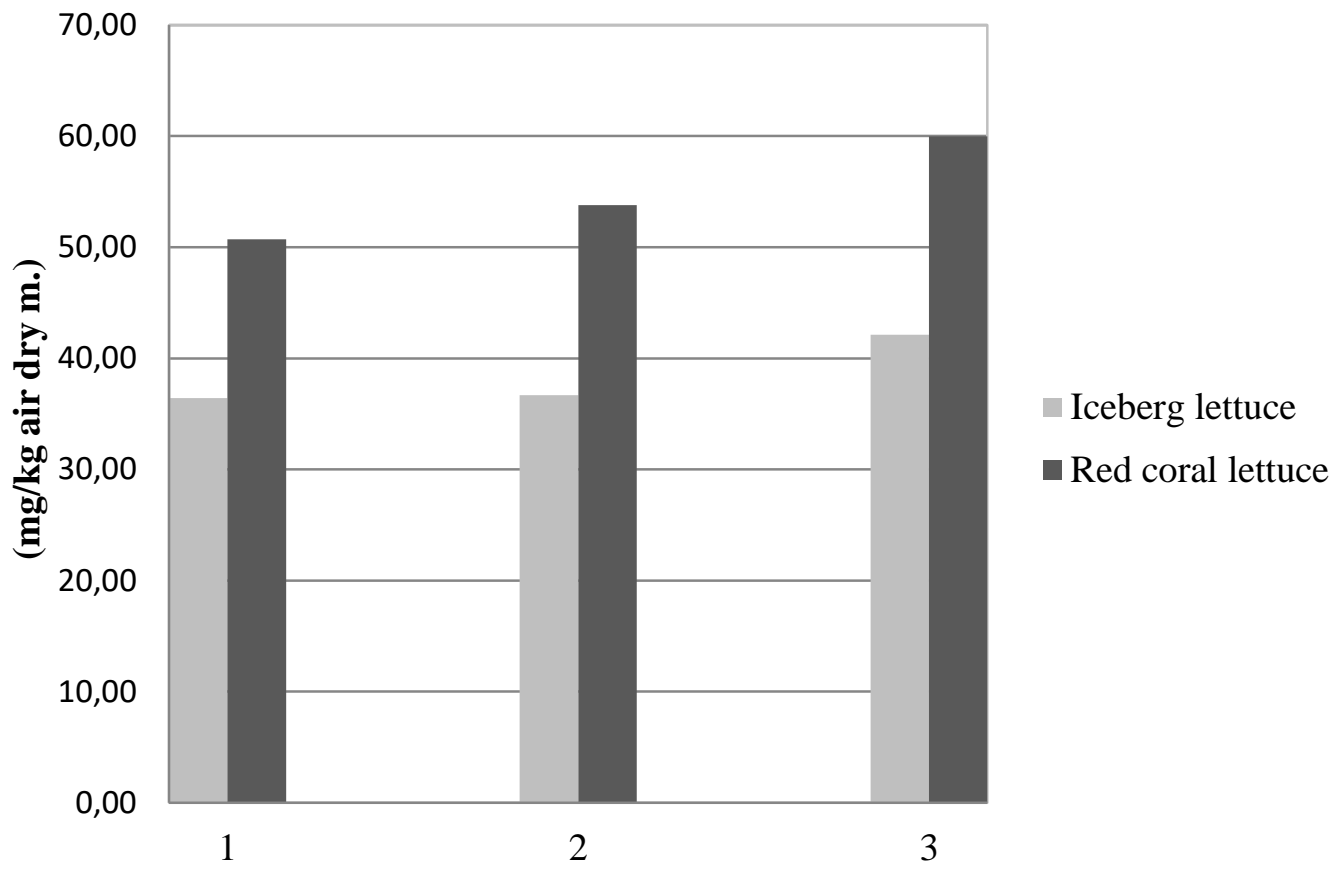

Figure 2. Changes in the $\mathrm{Zn}$ content of lettuce as a result of treatments

It can be seen that in the case of iceberg lettuce, the zinc content of the plant leaves increased only slightly with increasing zinc doses, while in the case of coloured lettuce, the zinc content of the leaves increased proportionally with increasing dose. We measured $150 \%$ higher zinc content in this type of lettuce as in the case of iceberg lettuce.

\section{Discussion, conclusion}

From the obtained results we can make the following conclusions:

- As zinc doses increased, the zinc content of the lettuce heads increased too. According to the literature, $100 \mathrm{~g}$ of fresh lettuce contains $0.15-0.20 \mathrm{~g}$ of zinc, which means $25-50 \mathrm{mg} / \mathrm{kg}$, calculated on an air-dry sample. The values measured during our experiment exceeded this.

- The higher amount of zinc did not reduce the size and quality of the lettuce head $(0.25 \mathrm{mg} / \mathrm{I}$ in the standard nutrient solution is the recommended amount of $\mathrm{Zn}$ ).

- Refining of the values and the reliability of the experiment, require further experiment setup during the spring growing season, and even higher zinc doses will be applied. 


\section{Acknowledgment}

Thank for the support of the research carried out in the framework of the EFOP-3.6.2-162017-00012 „Developing a functional, healthy and safe food product chain model from field to table in a thematic research network". The project is funded by the Hungarian State and the European Union, co-financed by the European Social Fund, and is part of the Széchenyi 2020 program.

\section{References}

[1] BÍRÓ, GY.-DWORSCHÁK, E.- ZAJKÁS, G.(1997): Élelmiszerek az egészségmegőrzésben. Budapest. Béres Rt. $113 p$

[2] BÍRÓ GY.(2013): Funkcionális élelmiszerek, természetes antioxidánsok szerepe az egészségmegőrzésben(http://www.kfki.hu/chemonet/osztaly/eloadas/birgyorgy.html)

[3] EARL, M.(1985): Vitamin biblia, Glória Kiadó.

[4] SCHNEIDER, E.(2001). Krauterals Funktionelle Lebensmittel: Rechtliche Stellung-Sicherheit-Qualitat. Deutsche Lebensmittel-Rundschau.

[5] SZABÓ P. B. (2012): Élelmiszerek és az egészséges táplálkozás. „Élelmiszerbiztonság és gasztronómia vonatkozású egyetemi együttmüködés, DE-SZTE-EKF-NYME TÁMOP pályázat

[6] TERBE, I.(2000): Levélzöldségfélék termesztése. Szaktudás Kiadó Ház, Budapest.

[7] TERBE, I.-SLEZÁK, K.(2019): Talajnélküli zöldséghajtatás. Mezőgazda Kiadó, Budapest. 